\title{
HISTORICIZANDO AS VERDADES CURRICULARES EM TEMPOS DE DEMOCRACIA: a alquimia dos conhecimentos geográficos e a fabricação de professores e estudantes no Brasil
}

\author{
Gabriel Pedro \\ Universidade Federal do Rio de Janeiro - UFRJ \\ Marcia Serra Ferreira \\ Universidade Federal do Rio de Janeiro - UFRJ
}

\begin{abstract}
Resumo
O texto objetivo investigar, em tempos democráticos no Brasil, o modo como as Ciências Sociais vieram participando dos processos de fabricação dos sujeitos escolares. No diálogo com Michel Foucault e alguns de seus interlocutores no campo do Currículo (Ian Hacking; Kathryn Kirchgasler; Thomas Popkewitz), produzimos uma análise comparativa e descontínua entre períodos históricos pautados por experiências institucionalmente democráticas no país: entre o fim do Estado Novo (1946) e o Golpe Militar (1964); a partir da Constituição de 1988. Analisando textos curriculares relativos aos Estudos Sociais e ao componente curricular Geografia na BNCC, interessa-nos perceber o modo como as verdades do ensino vieram se constituindo no país, com efeito no modo como viemos produzindo os conhecimentos e sujeitos da escolarização. A intenção é dar visibilidade a como certos princípios classificatórios, recontextualizados e reativados, operam linhas de diferenciação entre sujeitos escolares. Ao problematizar os processos discursivos que participaram ativamente da constituição de professores eficazes na formação de estudantes como cidadãos democráticos e cientificamente capazes, podemos contribuir para desestabilizar as verdades curriculares em tempos de democracia.
\end{abstract}

Palavras-chave: História do Currículo; Educação democrática; Alquimia das disciplinas escolares; Conhecimentos geográficos.

\begin{abstract}
The objective of the text is to investigate, in democratic times in Brazil, the way in which the Social Sciences came to participate in the manufacturing processes of school subjects. In dialogue with Michel Foucault and some of his interlocutors in the Curriculum field (Ian Hacking; Kathryn Kirchgasler; Thomas Popkewitz), we deployed a comparative and discontinuous analysis between two institutionally democratic periods in the country: between the end of the Estado Novo (1946) and the Military Coup (1964); and from the 1988 Constitution onwards. Analyzing curricular texts related to Social Studies and the Geography curricular component of the $B N C C$, we are interested in understanding how the truths of teaching came to be constituted in the country, affecting the way we have been producing the knowledge and the subjects of schooling. The intention is to give visibility to how certain classificatory principles, recontextualized and reactivated, operate lines of differentiation between school subjects, in the early twentieth century and today. By problematizing the discursive processes that participated in the constitution of effective teachers in the formation of students as democratic and scientifically capable citizens, we can contribute to destabilize curricular truths in times of democracy.
\end{abstract}

ISSN 1645-1384 (online) www.curriculosemfronteiras.org 
Key-words: Curriculum History; Democratic education; Alchemy of school subjects; Geographic knowledge. 


\section{Introdução}

Esse texto tem por objetivo investigar, em tempos democráticos no Brasil, o modo como as Ciências Sociais vieram participando dos processos de fabricação de tipos de sujeitos escolares (HACKING, 2007). Para realizar essa tarefa, produzimos uma análise comparativa e descontínua (KIRCHGASLER, 2017) entre dois períodos históricos onde travaram-se experiências institucionalmente democráticas no país: entre o fim do Estado Novo em 1946 e o Golpe Militar de 1964; a partir da Constituição de 1988. Interessa-nos perceber o modo como as verdades do ensino vieram se constituindo no país, com efeito no modo como viemos produzindo os conhecimentos e os sujeitos da escolarização.

No Brasil, a educação escolarizada se organizou sendo constantemente atravessada por retóricas sobre a inclusão, o autoaperfeiçoamento, a participação política e a emancipação. Isso ocorreu, por exemplo, durante a primeira metade do século $\mathrm{XX}$, quando o movimento escolanovista propôs reformas alinhadas às ideias progressivistas de John Dewey (FRANÇA, 2013 , p. 40). Outro interessante exemplo pode ser evidenciado no modo como a Pedagogia Crítica, sob os auspícios da Escola de Frankfurt, emerge na cena internacional durante a década de 1970 visando a emancipação do sujeito e a revolução societária de estruturas sociais elitistas e conservadoras (FRIEDERICH, JASTAAD \& POPKEWITZ, 2010, p. 573), alcançando o contexto brasileiro na década seguinte - os anos de 1980 -, em meio à Ditadura Militar pela qual passava o país.

Nesse processo, a instituição escolar foi concebida sendo enquadrada, ainda que não de forma exclusiva, por narrativas de democratização e de modernização do Brasil, um projeto que seria implementado por meio da educação de seus cidadãos. Centrais para esta organização foram as Ciências Sociais e uma noção epistemológica, bastante recorrente no início do século passado, de que nestas ciências residiria o potencial para antecipar e conduzir os fenômenos sociais, de forma a direcionar os resultados de planos civilizatórios para o futuro (CARVALHO, 1957, p. 77). A crença no potencial das Ciências Sociais como as arquitetas de uma sociedade mais igualitária, inclusiva e justa não se limitava à capacidade das instituições republicanas de fazerem valer um programa progressista por meio de ferramentas emprestadas da Sociologia, Geografia ou História; no Brasil, no contexto do movimento escolanovista entre as décadas de 1930 e 1960, este projeto democrático se dá no nível do indivíduo, onde o ensino das Ciências Sociais daquele então foi articulado na proposta da disciplina escolar Estudos Sociais (CARVALHO, 1957; NADAI, 1988; FRANÇA, 2013; MORAES, 2017; NASCIMENTO, 2019). Não é por acaso, portanto, que parte do nosso arquivo de pesquisa se refere a esse tempo histórico e à disciplina escolar Estudos Sociais.

Ainda que o enfoque em retóricas de educação democrática associadas aos Estudos Sociais já se mostrasse, em um primeiro momento, como um caminho profícuo de investigação acadêmica, este se tornou um imperativo a partir da configuração do golpe de estado contra a presidenta eleita Dilma Rousseff, consubstanciado na cassação de seu mandato ao fim do processo de impeachment em 31 de agosto de 2016 ${ }^{1}$. O Brasil vem vivendo uma crise institucional em nosso sistema de representação política desde aquela data, 
tendo presenciado a subversão de uma eleição presidencial democrática por meio de frágeis argumentações jurídicas e de motivações políticas ambíguas. Esta crise tem produzido reverberações controversas e impopulares em diversos setores da sociedade: na questão de investimentos públicos em serviços sociais ${ }^{2}$, na legislação trabalhista ${ }^{3}$, na Educação Básica, por meio de reformas curriculares decididas unilateralmente e implementadas a toque de caixa. Nesse contexto, tanto os sentidos de democracia mobilizados em diferentes tempos históricos quanto as condições enunciativas (FOUCAULT, 2015) da emergência de discursos sobre educação democrática vieram para o centro da construção do nosso objeto de análise.

Em tal empreitada investigativa, portanto, consideramos a possibilidade de que alguns dos critérios de categorização de sujeitos escolares da primeira metade do século XX tenham se imbricado tacitamente nas "infraestruturas conceituais e institucionais" (KIRCHGASLER, 2017, p. 88) da educação escolar. Nesse movimento, os princípios classificatórios se articularam como "transcendentais históricos" (KIRCHGASLER, 2017, p. 89), sem levar em conta os processos históricos de formulação destes princípios, cuja neutralização histórica possibilita sua reativação na operacionalização do ensino de conhecimentos geográficos na área de Ciências Humanas da BNCC. Nossos questionamentos precisaram problematizar, então, como se organizaram estes princípios como objetos epistemológicos social e culturalmente elaborados, específicos a um determinado momento histórico e território. Dirigir a atenção para estes processos históricos de formulação significou perguntar, por exemplo: Como se configuraram as feições epistemológicas nos dois momentos focalizados? Quem é professor eficaz para o ensino das Ciências Sociais nesses tempos históricos? Como se esperava e se espera que este professor prepare seu estudante e mensure o sucesso do mesmo com vistas a torná-lo um cidadão democraticamente responsável e cientificamente capaz? Quais são as características deste tipo de cidadão que o aluno deveria vir a ser? Foi com questões como essas que organizamos nossas reflexões acerca da fabricação desses tipos de pessoas na escola.

\section{Investigar as verdades que fabricam os sujeitos da educação: por entre moinhos de vento epistemológicos e alvos em movimento}

Nessa seção, associamos o uso da noção de subjetivação (FOUCAULT, 1995) ao conceito de fabricação de tipos de pessoas (HACKING, 2007), assumindo que ambos apresentam características em comum. Fazemos isso a partir da noção foucaultiana de como certos campos de conhecimento tidos como legítimos ${ }^{4}$ em determinado momento sóciohistórico criam objetos discursivos ao "delimitar seu domínio, de definir aquilo de que fala, de dar-lhe status de objeto - ou seja, de fazê-lo aparecer, de torna-lo nomeável e descritível" (FOUCAULT, 2015, p. 50-51), aproximando-a da afirmação de que certos "tipos de pessoas não teriam existido, enquanto tipos de pessoas, até terem sido classificados de tal maneira" (HACKING, 2007, p. 288, tradução nossa). Essa ideia de legitimidade a qual nos referimos não diz respeito a julgamentos de valor acerca do que é verdadeiro ou falso, mesmo que esse julgamento leve em conta a época em que se vive. A preocupação de Michel Foucault foi 
menos com uma economia da verdade, ou seja, de que maneira a verdade se distribuiu, se concentrou ou se escasseou ao longo de instituições e linhas de pensamento divergentes; sua atenção direcionou-se mais a uma política da veridição (BECKER; EWALD; HARTCOURT, 2012, p. 5), visando a explorar os jogos de poder relacionais que organizam os discursos socialmente aceitos em dada época e que enunciam verdades sobre um dado conjunto de objetos, assim como quais são os sujeitos capazes de utilizar estes discursos e serem ouvidos.

Nesse mesmo movimento, percebemos que as práticas discursivas de classificação que constituem tais delimitações entre sujeitos são realizadas por meio de relações de alteridade, "no seu interior e em relação ao outro" (FOUCAULT, 1995, p. 231), o que significa que pensar sobre o pertencimento de alguns grupos de pessoas à certas sociedades implica, necessariamente, pensar "em outras pessoas, os excluídos" (HACKING, 2007, p. 286, tradução nossa) desse pertencimento. Por fim, entendemos que a construção das diferenciações entre sujeitos por meio de práticas discursivas constituem "o modo pelo qual o ser humano torna-se um sujeito" (FOUCAULT, 1995, p. 232) e se reconhece a partir de certas características, "concebidas como e experienciadas como jeitos de ser uma pessoa" (HACKING, 2007, p. 285, tradução nossa).

Tais características em comum referem-se ao fato de que Ian Hacking (2007), ao formular a noção de fabricação de tipos de pessoas, estabelece um explícito diálogo com Michel Foucault, abordando uma forma específica de subjetivação ao propor investigar, em um campo que denominou de nominalismo histórico dinâmico, os efeitos de poder que o ato de nomeação exerce sobre os sujeitos e as condições sócio-históricas de tal enunciação. Para realizar essa tarefa, o autor elenca cinco elementos interativos e não-sequenciais, no processo de fabricação (HACKING, 2007, p. 298-297), que apresentam maior ou menor importância no arcabouço explicativo, a depender de qual tipo de sujeito é focalizado e a partir de qual perspectiva. São eles: (a) a classificação, onde um ato de nomeação, a partir de algum objetivo ou preocupação social, constitui um tipo de pessoa que previamente não existia daquela maneira; $(b)$ os indivíduos em si, agrupados a partir de um conjunto de características pensadas como comuns a todos e que justificam a necessidade da classificação; (c) as instituições, como espaços que atribuem legitimidade à categorização como objeto discursivo, fazendo a ressalva de que o autor não pensa, exclusivamente, em sítios de produção dos conhecimentos acadêmicos, mas também a partir de outras entidades deliberadamente organizadas e estruturadas para abordar a questão; $(d)$ o corpo de conhecimento em constante evolução e que trata do objeto discursivo, constituído não apenas por saberes experts, operacionalizados pelos profissionais treinados, mas também os saberes populares compartilhados por boa parte da população interessada e que, mesmo sem o rigor procedimental exigido dos saberes experts, produz efeitos discursivos de subjetivação; (e) e os próprios experts, que se relacionam com todos os outros elementos, uma vez que são eles que:

geram ou legitimam o conhecimento $(d)$, julgam sua validade, e o usam em suas práticas. Eles trabalham em $(c)$ instituições que garantem sua legitimidade, 
autenticidade e status enquanto experts. Eles estudam, tentam ajudar, ou aconselhar no controle, das $(b)$ pessoas que são $(a)$ classificadas como sendo de um dado tipo (HACKING, 2007, p. 297, tradução nossa).

Tais elementos se articulam em uma abordagem que nos possibilita pensar a fabricação dos tipos de sujeitos como alvos em movimento. Afinal, se os processos de classificação por meio dos quais os indivíduos são fabricados em tipos de sujeitos transforma continuamente a maneira como estes pensam sobre si e as maneiras como experienciam diferentes momentos, então, ao longo destes processos, estes sujeitos não são mais os mesmos, não sendo mais os alvos originais de determinadas práticas discursivas de confinamento epistemológico. Isso significa compreender que estes tipos de sujeitos "são alvos em movimento porque nossas investigações interagem com eles, e os modificam. E como eles mudaram, não são mais as mesmas pessoas que antes. O alvo se moveu" (HACKING, 2007, p. 293, tradução nossa). Nessa perspectiva, tanto as categorias que distinguem os tipos de sujeitos escolares quanto os próprios alvos das distinções são percebidos como invenções ou, dito de outra forma, como uma articulação de objetos discursivos ao invés de uma descoberta de objetos ontológicos. Estas invenções são organizadas discursivamente como respostas a demandas ou preocupações da sociedade, estruturando padrões tidos como razoáveis no momento sócio-histórico que também produz as expectativas que visa a satisfazer. Estes padrões nos possibilitam certos modos (e não outros) de pensar sobre as questões educacionais e desenvolver linhas de ação possíveis para atuar sobre o que foi constituído como um problema social. É nesse movimento que as soluções curriculares do presente entram no verdadeiro, equacionando as experiências passadas com as expectativas de futuro (KOSELLECK, 2006).

Isso significa entender que as práticas discursivas, ao se arriscarem na tarefa de confinamento epistemológico dos sujeitos, irão estar sempre perseguindo moinhos de vento epistemológicos. Como Dom Quixote ao atacar seus gigantes, o ímpeto de tal perseguição é compreensível, ainda que ilusório e, portanto, fadado ao fracasso. Afinal, o ato de nomear os sujeitos é também transfigurá-los e, portanto, perdê-los; o efeito de tal movimento é a categoria em si, ou melhor, um espaço discursivamente formulado no âmbito do qual os próprios sujeitos passam a pensar sobre eles mesmos e suas escolhas (POPKEWITZ, 2012, p. 173-174) e sobre o qual a sociedade pode planejar atuações, operar transformações e disputar sentidos. Na próxima seção, explicitamos a abordagem discursiva por meio da qual viemos produzindo uma análise histórica comparativa e descontínua (ver, por exemplo, PEDRO, 2020), em estreito diálogo com o modo como o Grupo de Estudos em História do Currículo vem se apropriando da noção de alquimia das disciplinas escolares, tal como formulada por Thomas Popkewitz (2001) ${ }^{5}$. 


\section{Por uma História do Currículo comparativa e descontínua: entre linhas que separam e estabilidades incontestadas}

Como apontado anteriormente, esta pesquisa enquadrou seus objetos e questionamentos a partir de uma abordagem histórica comparativa e descontínua para o campo curricular, em direto diálogo com a abordagem discursiva que tem sido desenvolvida no Grupo de Estudos em História do Currículo (FERREIRA, 2013 e 2015; FERREIRA; MARSICO, 2020; FERREIRA; SANTOS, 2017), no diálogo com Thomas Popkewitz e a noção de alquimia das disciplinas escolares (POPKEWITZ, 2001). Segundo o autor, este conceito descreve um conjunto de processos discursivos de construção dos currículos disciplinares por meio dos quais se constituem lógicas de organização das práticas de ensino e, simultaneamente, se inscrevem normas de classificação, separação e exclusão dos sujeitos escolares. Ele envolve uma mistura de práticas em três níveis, imbricados e não desconexos, que são: a divisão do conhecimento em fragmentos de informação, organizando-o em um sequência linear e natural que possibilita focar menos no conhecimentos e mais nos estudantes; os recursos textuais, dentre os quais os livros didáticos, fixando e estabilizando códigos morais por meio dos quais comparamos e situamos esses estudantes; as avaliações, em suas diferentes formas, conectando mais uma vez os conhecimentos com as subjetividades ao dar ordenamento às práticas de ensino e à classificação dos estudantes a partir dos resultados obtidos, categorizando-os a partir das expectativas do que deveriam ter aprendido. É a partir destas normas de classificação, separação e exclusão, operacionalizadas por meio de processos alquímicos, que são fabricados os tipos de pessoas na escola.

$\mathrm{Na}$ alquimia das disciplinas escolares, um elemento que operacionaliza estes processos de fabricação dos tipos de pessoas é uma espécie de desvinculação histórica dos conhecimentos a serem ensinados, apresentando o mundo a partir de uma perspectiva da disciplina escolar como objeto da lógica, uma entidade estável. Nesse movimento:

Enquanto as disciplinas [acadêmicas] envolvem conjuntos de ideias rivais sobre pesquisa (podemos chamá-los de paradigmas), as matérias escolares tendem a tratar o conhecimento como um conteúdo inconteste e claro para as crianças aprenderem ou com eles resolverem problemas. Os conceitos e as generalizações são encarados como estruturas lógicas, não-temporais, que funcionam como bases a partir das quais ocorre a aprendizagem. Até mesmo os métodos de pesquisa são considerados entidades lógicas que seguem algumas regras de método científico que existem fora dos processos sociais, tais como aprender as 'habilidades de laboratório’ ou as práticas de entrevista. Desse modo, no ensino, é possível falar que a aprendizagem das crianças envolve a compreensão e má compreensão dos conceitos, como se estes fossem entidades de conhecimento estáveis e fixas (POPKEWITZ, 2001, p. 35).

No diálogo com Kathryn Kirchgasler (2017, p. 88), consideramos a possibilidade de que algumas destas linhas de diferenciação tenham se imbricado tacitamente nas "infraestruturas conceituais e institucionais" da educação escolar brasileira, com efeitos em componentes 
curriculares como os Estudos Sociais e a Geografia. Por meio de processos alquímicos, assumimos que os conhecimentos das Ciências Sociais vieram se transformando em disciplinas escolares que atuam na produção de princípios classificatórios como "transcendentais históricos" (KIRCHGASLER, 2017, p. 89), participando dos processos de fabricação de tipos de sujeitos escolares (HACKING, 2007). Nesse cenário, como já explicitado, o movimento analítico proposto é comparativo e descontínuo (KIRCHGASLER, 2017), em consonância com deslizamentos teórico-metodológicos provocados pelas formulações de Michel Foucault que vieram se rebelando contra tendências da pesquisa histórica que, na primeira metade do século XX, consolidavam certas "continuidades irrefletidas pelas quais se organizam, de antemão, os discursos que se pretende analisar" (FOUCAULT, 2015, p. 30). Tal postura significou não apenas a rejeição da mobilização de categorias e de interpretações atravessadas por sentidos de continuidade, linearidade e/ou unidade anteriores a análise, como também condicionou uma delimitação porosa dos currículos como objeto de estudo.

Segundo Michel Foucault (2015, p. 28), aquilo que se assume nas investigações históricas como coerência interna é variável e relativo, uma vez que "só se constrói a partir de um campo complexo de sentidos" que não se apresenta imediatamente e não é acessível de maneira orgânica. Para ele, diferentemente, essa coerência interna é uma operação interpretativa que constitui a unidade ao invés de precedê-la. Isso significa assumir a descontinuidade como uma importante ferramenta metodológica para a desestabilização das verdades sedimentadas, desnaturalizando-as com o intuito de tornar visíveis as relações discursivas que tornaram possível a irrupção de um certo acontecimento ao invés de outros possíveis (FOUCAULT, 2015). A descontinuidade dos acontecimentos não é, portanto, um aspecto a ser combatido nos estudos históricos; ela é uma característica que produz os nossos objetos e valida as nossas análises (FERREIRA, 2013). É justamente nessa direção que Kathryn Kirchgasler (2017) lança mão da noção de "transcendentais históricos", entendendo que estes são efeitos da alquimia das disciplinas escolares que, ao descolar os conhecimentos de seus processos sociais de produção, naturaliza e torna lógico tudo aquilo que tem história. A ideia é, portanto, dar visibilidade às condições de enunciação dos acontecimentos, entendendo-as como social e culturalmente produzidas, histórica e espacialmente localizadas, ainda que tenham se tornado neutras e opacas por meio dos processos alquímicos (POPKEWITZ, 2001).

É nesse contexto que optamos por investigar o modo como as Ciências Sociais, em tempos democráticos, vieram participando dos processos de fabricação de tipos de pessoas por meio da alquimia que produziu, em tempos históricos distintos, as disciplinas escolares Estudos Sociais e Geografia. O exercício de historicizar comparativamente o ensino disciplinarizado dos conhecimentos geográficos é, antes de mais nada, um exercício de salientar as condições enunciativas de formação de determinados discursos educacionais ao invés de outros, evidenciando os arranjos epistemológicos que fizeram com que certos objetos discursivos se tornassem visíveis e possíveis de serem pensados, participando daquilo que conta como verdade sobre o tema no tempo presente. 
Tal tarefa reflexiva significa afirmá-los todos - a escola, os conhecimentos geográficos, a criança e o professor - como montagens contingenciais e específicas, o que nos permite pensar sobre como são (re)ativadas as linhas de diferenciação entre os sujeitos escolares das Ciências Sociais, em diferentes momentos de democracia institucional, olhando para os Estudos Sociais entre 1946 e 1964 e, simultaneamente, para a disciplina escolar Geografia no tempo presente. Para focalizar estes dois momentos, nosso arquivo de pesquisa está organizado com as seguintes fontes: (i) o manual didático Introdução Metodológica aos Estudos Sociais, publicado em 1957 por Carlos Delgado de Carvalho, analisado em diálogo com o Manifesto dos Pioneiros da Educação Nova (1932) e o Manifesto dos Educadores, Novamente Convocados (1959), com vistas a investigar os sentidos de educação democrática mobilizados pelo movimento escolanovista, considerados como condições enunciativas da disciplina escolar Estudos Sociais no período; (ii) seções específicas da Base Nacional Comum Curricular (MEC, 2018a). São elas: a Introdução, onde se explicitam conceitos e linhas gerais de organização; a seção intitulada A Etapa do Ensino Fundamental, com pausada atenção para as competências delineadas para este segmento; a seção nomeada $A$ área de Ciências Humanas, visando a compreender os procedimentos por meio dos quais os limites epistemológicos dessa área foram traçados; por fim, as seções Geografia no Ensino Fundamental - Anos Iniciais e Geografia no Ensino Fundamental - Anos Finais, nas quais se delineiam as competências, unidades temáticas, objetos de conhecimento e habilidades específicas do componente curricular em questão. É analisando esse arquivo que, na próxima seção, abordamos o modo como as Ciências Sociais, por meio das referidas disciplinas escolares, vieram, por meio de processos alquímicos, limitando os espíritos e disciplinando os conhecimentos a serem ensinados nos tempos históricos aqui investigados.

\section{Limitações do espírito e interdisciplinaridades que disciplinam: desenhando as Ciências Sociais na escola em tempos democráticos}

De maneira a interpelar o currículo de Ciências Sociais proposto no contexto brasileiro na primeira metade do século XX - isto é, entre 1946 e 1964 -, lançamos o nosso olhar para a disciplina escolar Estudos Sociais, que tem sido historicamente percebida de forma estigmatizada em nosso contexto educacional, uma vez que recebeu notoriedade e foi implementada em uma escala mais ampla durante a Ditadura Militar. No entanto, ao historicizar os Estudos Sociais em tempos democráticos, percebemos em sua alquimia a articulação de outros discursos, associados à projetos de reformas educacionais advindas do movimento escolanovista e que visavam o envolvimento da escola com a vida social e comunitária, afirmando o papel da mesma em uma sociedade mais democrática e harmoniosa (MORAES, 2017). Para realizar essa tarefa, essa instituição deveria ser laica, gratuita, obrigatória e cientificamente orientada, respeitando a natureza federativa da república brasileira. Além disso, ela deveria veicular conhecimentos escolares voltados para as questões vitais do dia-a-dia dos estudantes, visando a inculcar nos futuros cidadãos ideais de 
democracia, preparando o país para os desafios e oportunidades do mundo moderno e industrial (AZEVEDO et al., 2010).

No material investigado, sentidos de modernidade são mobilizados como um objeto epistemológico, delineado como uma "torrente invencível de transformações" contra a qual "não está no poder dos homens resistir-lhe, está na sua sabedoria canalizá-la, na direção que lhes compete descobrir" (AZEVEDO et al., 2010, p. 28). Os significados de ensino mobilizados nestes documentos têm uma relação intrínseca com essas noções de mudanças progressivas e irrefreáveis do tempo; o ensino democrático, neste momento histórico, é interpretado como o único capaz de direcionar a escola para alcançar os objetivos propostos pela Escola Nova. A democracia é caracterizada, assim, como uma consequência inevitável da evolução da humanidade moderna, visando uma convivência harmoniosa. É nesse mesmo movimento que a educação democrática é enunciada como necessária para concretizar este projeto de sociedade, articulando um duplo gesto (POPKEWITZ, 2001) de esperança para a sociedade que está por vir e, simultaneamente, de medo de que este projeto societário não se concretize.

Nesse contexto, a necessidade da disciplina escolar Estudos Sociais no ensino fundamental é discursivamente produzida a partir da afirmação de que "o abismo existente entre o progresso material da nossa civilização e o atraso mental do momento é a tragédia do mundo moderno e cada vez irá se acentuando se a Educação não preparar os indivíduos para o meio em que estão chamados a viver" (CARVALHO, 1957, p. 72-73). Em tal movimento, o manual didático participa da produção de um sentido específico de modernidade para o campo educacional, no qual as mudanças que esta produz são irrefreáveis e progressivas, atribuindo-lhe uma qualidade quase teleológica (TENÓRIO, 2009). Ainda que tal compreensão acerca dos tempos modernos não tenha sido exclusiva do movimento escolanovista brasileiro, enfatizamos que o mundo por vir que aqui se acreditou inexorável não foi associado ao american way of life, como fizeram alguns proponentes estadunidenses da disciplina escolar (MICHAELIS, 1970); ao invés disso, ele foi pareado com as noções mais abrangentes de "processo civilizatório" e de "patriotismo internacional" (CARVALHO, 1957, p. 108). No caso brasileiro, o papel da disciplina escolar Estudos Sociais seria o de "dar ao educando o sentido mundial, indispensável ao homem educado moderno" (CARVALHO, 1957, p. 113), por meio dos seguintes objetivos:

1 - Conhecer e compreender os conceitos sociais e os valores das instituições. 2 - Desenvolver, no indivíduo, a capacidade de estudar, ler e interpretar, com senso crítico, o que leu, ouviu ou viu. 3 - Despertar a personalidade do educando, desenvolvendo seus interesses culturais e seu senso de responsabilidade. 4 Integrar o indivíduo na sociedade democrática em que deve viver, promovendo sua cooperação como bom cidadão. 5 - Compreender a interdependência das Nações no mundo moderno, respeitando as funções particulares dos diferentes grupos e contribuindo à compreensão internacional (CARVALHO, 1957, p. 65). 
Com tais objetivos, torna-se possível começar a delinear os contornos discursivos do tipo de pessoa que esta proposta educacional almeja formar: o cidadão democrático, cientificamente capaz e munido de uma forma específica de patriotismo, de cunho internacional. Os comportamentos democráticos que se pretende incutir são conformados a partir de práticas coletivas, cooperativamente construídas entre estudantes e professores, sendo necessárias avaliações contínuas ao longo de todo o processo, com atenção voltada para as características atitudinais da criança. O próprio espaço da sala de aula no qual se realizam as atividades dos Estudos Sociais deve ter "feições democráticas", visando a "uma cooperação social mais perfeita" (CARVALHO, 1957, p. 145). Para realizar essa tarefa, o currículo da disciplina escolar é produzido a partir de diferentes campos epistemológicos, tais como a História, a Economia, a Sociologia, a Política, a Geografia Humana e a Antropologia (CARVALHO, 1957, p. 14). O entrecruzamento dessas ciências de referência na alquimia da disciplina escolar Estudos Sociais aponta para uma postura epistemológica na qual a "fusão das matérias resulta do fato da ciência ser UNA; nós é que a subdividimos para comodidade do estudo, do ensino, da própria limitação do espírito" (CARVALHO, 1957, p. 15). Tal postura epistemológica salienta, ainda, que "nas ciências sociais, o isolamento é difícil, artificial: política, economia, história, sociologia, em certo grau de estudo, se completam de tal modo que caem as divisões fixadas para sua mais fácil apreensão" (CARVALHO, 1957, p. 87). Ainda nessa direção, o manual didático recomenda que a sua organização seja levada a cabo considerando cinco bases ${ }^{6}$ : a filosófica, a sócioeconômico-política, a psicológica, a administrativa e a científica. Sendo enunciada como polivalente, uma vez que operacionaliza ciências de referência distintas, essa organização ocorre por meio de unidades, que geralmente focalizam um "aspecto significativo das relações humanas" (CARVALHO, 1957, p. 161-162): na História, é favorecida a constituição de unidades pela cronologia; em Geografia, pelos gêneros de vida; em Sociologia, pelos processos sociais de concorrência, conflito, ajustamento, assimilação e outros" (CARVALHO, 1957, p. 14).

Essa organização é realizada sobre uma estrutura de seriações por graus, relacionados com faixas etárias recomendadas, as quais formulam expectativas psicobiológicas para o desenvolvimento da criança. O modelo de círculos concêntricos (NASCIMENTO, 2019; PASCAL, 2016; CALLAI, 2005) se articula, no documento investigado, com tal estrutura. Ele é, em resumo, uma abordagem por meio da qual os conhecimentos são tratados progressivamente a partir das realidades mais próximas dos estudantes, avançando progressivamente para o ensino de contextos mais afastados e complexos na medida em que estes vão envelhecendo. O manual didático formula, por exemplo, que entre os sete e oito anos de idade "o ensino da Geografia é tido por inadequado", cabendo ao professor apenas "ajudar os alunos a observar fatos geográficos em que eles vivem” (CARVALHO, 1957, p. 96); já entre os oito e dez anos, a criança "nas coisas só vê detalhes, pois seu conhecimento é analítico e suas percepções deixam de ser globais e vagas" (CARVALHO, 1957, p. 98), sendo capaz de articular conceitos mais complexos, assim como estabelecer relações imediatas entre eles; por fim, a partir dos onze ou doze anos em diante, "dá-se uma alteração psicológica passando a criança a dominar o mundo exterior em vez de ser dominado por ele", 
se tornando capaz de "abstração, percebendo relações que existem entre fatos concretos diversos" (CARVALHO, 1957, p. 98). Todos estes elementos participaram da alquimia da disciplina escolar Estudos Sociais entre os anos de 1946 e 1964, produzindo efeitos na fabricação dos tipos de pessoas (HACKING, 2007) na escola.

Buscando produzir uma história comparativa e descontinua que articule essa alquimia à aquela que, no tempo presente, também possibilita a participação das Ciências Sociais na constituição de uma Base Nacional Comum Curricular (BNCC), evidenciamos o quanto as necessidades educacionais que sustentam os objetivos da disciplina escolar Geografia são outros, ainda que lancem mão de categorias aparentemente similares. Tais necessidades se articulam à defesa da existência de um projeto normativo que auxilie na organização dos currículos escolares em todo o território nacional, de maneira que tal iniciativa "ajude a superar a fragmentação das políticas educacionais, enseje fortalecimento do regime de colaboração entre as três esferas de governo e seja balizadora da qualidade da educação" no país (MEC, 2018a, p. 8). As necessidades do ensino escolar brasileiro, assim articuladas, são operacionalizadas pela noção de aprendizagens essenciais, com vistas a garantir os direitos de aprendizagem e desenvolvimento, caracterizadas como um conjunto de aprendizagens "orgânico e progressivo que todos os alunos devem desenvolver ao longo [...] da Educação Básica" (MEC, 2018a, p. 7). Ainda assim, o documento se reafirma como uma diretriz e não como uma prescrição curricular ao apontar como responsabilidade das secretarias de educação dos diferentes entes federativos "as decisões curriculares e didático-pedagógicas [...], o planejamento do trabalho anual das instituições escolares e as rotinas e os eventos do cotidiano escolar devem levar em consideração a necessidade de superação dessas desigualdades" (MEC, 2018a, p. 15). Neste movimento, são mobilizados sentidos de igualdade e, simultaneamente, de equidade educacionais: um como responsabilidade das diversas secretarias de educação e instituições de ensino; outro da União, por meio da BNCC.

Os objetivos, garantias, procedimentos e valores que estes descritores buscam delinear foram operacionalizados no discurso da BNCC por meio dos conceitos de competências e habilidades. No documento, as competências são descritas como "a mobilização de conhecimentos (conceitos e procedimentos), habilidades (práticas, cognitivas e socioemocionais), atitudes e valores para resolver demandas complexas da vida cotidiana, do pleno exercício da cidadania e do mundo do trabalho" (MEC, 2018a, p. 8). As habilidades, por sua vez, não recebem definição explícita única, ainda que sejam enunciadas de modo quase intercambiável com as competências, aspecto que se alinha ao texto da LDB, alterado por força da lei $\mathrm{n}^{\mathrm{o}}$ 13.415/2017, que aborda ambos os conceitos como "maneiras diferentes e intercambiáveis para designar algo comum, ou seja, aquilo que os estudantes devem aprender na Educação Básica, o que inclui tanto os saberes quanto a capacidade de mobilizá-los e aplicá-los" (MEC, 2018a, p. 12).

O currículo oficial confere especial destaque aos parâmetros utilizados pelos exames padronizados internacionais de classificação dos sistemas educacionais implementados pela "Organização para a Cooperação e Desenvolvimento Econômico (OCDE), que coordena o Programa Internacional de Avaliação de Alunos (PISA, [...]) e da Organização das Nações Unidas para a Educação, a Ciência e a Cultura (Unesco, [...])" (MEC, 2018a, p. 13). Nas 
últimas décadas, avaliações em larga escala como o PISA, produtoras de comparações internacionais, têm se expandido radicalmente, muitas vezes usadas "na formulação de políticas, a fim de identificar e encontrar soluções para as crises internacionais" (POPKEWITZ; LINDBLAD, 2016, p. 732). Não é surpreendente, portanto, que seus critérios avaliativos participem da alquimia por meio da qual as Ciências Sociais se transformam em disciplinas escolares. Mas é significativo que as noções de competências e habilidades, como princípios organizacionais da BNCC, articulem sentidos de legitimidade e necessidade desse texto curricular de caráter nacional a partir de avaliações comparativas padronizadas e internacionais, trazendo-as para participar da constituição das reformas pretendidas. Afinal, diversos autores (SÜSSEKIND, 2014; CURY; REIS; ZANARDI, 2018; OLIVEIRA, 2018) já nos indicaram o quanto as avaliações em larga escala produzem efeitos nas práticas docentes e na organização dos sistemas educacionais públicos, regulando e homogeneizando os conhecimentos e sujeitos escolares ao estabelecer critérios de comparação que enfraquecem sentidos de diversidade e diferença.

No texto da BNCC, o uso do termo componente curricular para se referir às disciplinas escolares marca, segundo Heloize Charret (2019), um processo de ressignificação das disciplinas escolares. Para a autora, esse movimento é "realizado de forma tão assertiva que, ao longo de todo o documento legal, o termo disciplina não é sequer mencionado, a não ser por meio de citações literais de outros documentos normativos" (CHARRET, 2019, p. 60). Tais disputas por significar o modo de organização dos currículos escolares são tensionadas por meio da noção de áreas de conhecimento, assim como as de competências e habilidades, que questionam a organização disciplinar em meio aos discursos de (e sobre) integração curricular.

O tensionamento entre estas duas lógicas - organização disciplinar versus integração curricular - foi também notado por Hugo Heleno Costa e Alice Casimiro Lopes (2016) ao analisarem a disciplina escolar Geografia em textos curriculares oficiais anteriores à BNCC: os Parâmetros Curriculares Nacionais para o Ensino Médio (BRASIL, 1999) e suas Orientações Curriculares (BRASIL, 2006) e Complementares (BRASIL, 2002). Compreendendo a interdisciplinaridade como um dos sentidos que a integração curricular assume nas políticas contemporâneas para o ensino médio, esses autores evidenciam a regulação que o conhecimento disciplinar produz na significação do termo, sendo delineado como um traço disciplinar e, simultaneamente, como um elemento integrador do currículo. Em direção semelhante, Heloize Charret (2019) destaca que, no caso da BNCC, ainda que as disciplinas escolares estejam de certo modo apagadas, elas emergem sendo tratadas como análogas aos conhecimentos de referência, o que reifica a organização disciplinar e limita as possibilidades de pensar a integração curricular.

A integração curricular é aqui percebida como um enunciado que vêm regulando o modo como as Ciências Sociais se transforma, alquimicamente, em disciplina escolar. No caso dos Estudos Sociais, isso é feito por meio de unidades temáticas que se organizam em meio à lógica disciplinar: unidades cronológicas para os estudos de História; gêneros de vida para os estudos de Geografia; processos sociais de concorrência-conflito-ajustamento-assimilação para a Sociologia etc. (CARVALHO, 1957, p.161-162). Na BNCC, as unidades temáticas 
funcionam como eixos estruturantes estabelecidos previamente, para todas as séries, em meio aos quais se desenrolam as práticas docentes na interface com os conhecimentos disciplinares. No caso da Geografia, as cinco unidades temáticas são: "o sujeito e seu lugar no mundo"; "conexões e escalas"; "mundo do trabalho"; "formas de representação e pensamento espacial"; "natureza, ambientes e qualidade de vida" (MEC, 2018a, p. 362). Nelas, é possível perceber a articulação de objetivos de ensino-aprendizagem cada vez mais complexos, na medida em que a criança avança dos os anos iniciais para os anos finais do ensino fundamental, operacionalizando de certo modo um método análogo ao dos círculos concêntricos, uma prática historicamente tão criticada (NASCIMENTO, 2019; PASCAL, 2016; CALLAI, 2005).

No entanto, assumimos que as necessidades educacionais construídas nos dois momentos históricos, ainda que mobilizem linguagens similares, tem contornos epistemológicos destoantes. Afinal, nos Estudos Sociais, entre os anos de 1946 e 1964, as preocupações se articulavam em torno de uma garantia da oferta de educação gratuita, laica, obrigatória e universal, que era enunciada como necessária para a democratização da sociedade, em contraponto com tendências centralizadoras advindas do período do Estado Novo, assim como tendências privatizadoras que atacavam à época a escola publicamente gerida (AZEVEDO et al., 2010). A retórica política da BNCC, por sua vez, é constituída pela urgência da melhoria de uma educação pública em crise, associando essa melhoria à constituição de prescrições curriculares nacionais e comuns, com vistas à promoção de igualdade e equidade (SANTOS; FERREIRA, 2020).

Também as concepções de Ciências Sociais formuladas nos dois momentos históricos articulam pontos de vista epistemológicos destoantes, com efeitos no modo como pensam o papel da mesma na organização da sociedade e na formação do cidadão por meio da escolarização. Tanto a disciplina escolar Estudos Sociais quanto o componente curricular Geografia no âmbito da BNCC operam com noções de integração curricular na constituição alquímica de seus currículos. A primeira o faz em meio a uma postura epistemológica de compreender as Ciências Sociais como una (CARVALHO, 1957, p. 15), recolhendo em seu bojo tanto História e Geografia, quanto Sociologia, Economia, Política e Antropologia (CARVALHO, 1957, p. 14) a partir da crença em uma qualidade teleológica de um tipo específico de modernidade (TENORIO, 2009, p. 487). Nesse contexto, o conjunto dos conhecimentos dessas ciências de referência produziria ferramentas para interpretar, sistematizar e até certo ponto prever o futuro, administrando a sociedade em direção ao progresso, ainda que a disciplinarização empobrecesse a análise dos fenômenos sociais, sendo tal movimento de fragmentação um mal necessário devido à "limitação do espírito" humano (CARVALHO, 1957, p. 15).

A área de conhecimento das Ciências Humanas articulada pela reforma curricular da BNCC (2018), por sua vez, comporta apenas os componentes curriculares História e Geografia, não por uma postura epistemológica de integração, mas para produzir vias de circulação horizontal entre competências e habilidades em ambos os componentes curriculares. Este desenho curricular, entretanto, acabou por articular um discurso de integração curricular que mobilizou sentidos de interdisciplinaridade, estabelecendo "forte 
influência no processo de estabilização das disciplinas [escolares] no âmbito das propostas" (CHARRET, 2019, p.70). Ainda assim, a organização da área das Ciências Humanas na BNCC encerra disciplinas escolares tradicionais em um mesmo espaço organizacional, alinhando-se formalmente às recomendações de instituições como ONU, a OCDE e avaliações como o PISA (MEC, 2018a, p. 13), realizando um movimento que, pela via da interdisciplinaridade, acaba fortalecendo uma lógica disciplinarizada de formulação curricular. Ou seja, enquanto os Estudos Sociais no início do século XX direcionavam o olhar para um momento no futuro no qual as limitações do espírito humano não mais exigiriam a disciplinarização dos fenômenos sociais, a integração curricular proposta pela BNCC - da qual faz parte a Geografia - parece estar desapercebidamente em lealdade aos moldes disciplinares para pensar o currículo.

No entanto, o alvo dos processos de fabricação de tipos de pessoas (HACKING, 2007), em meio aos processos alquímicos que vieram produzindo as disciplinas escolares (POPKEWITZ, 2001) é, em ambos os casos, o estudante democraticamente responsável e cientificamente capaz, sendo ensinado por professores eficazes. É sobre essa questão que nos detemos na próxima seção, assumindo que mesmo no âmbito de processos históricos distintos de compartimentação/textualização/avaliação dos conhecimentos das Ciências Sociais, em particular os geográficos, ambos os componentes curriculares - os Estudos Sociais e a Geografia - puderam ativar semelhantes linhas de diferenciação.

\section{Os princípios classificatórios e a produção das verdades da escolarização: os sujeitos da escola são sempre os mesmos?}

No movimento escolanovista na primeira metade do século XX, a formação do cidadão para o futuro é enunciada como se dando por meio de práticas educacionais voltadas às "funções vitais" dos estudantes, ou seja, "que se propõe, antes de tudo, a desenvolver ao máximo a capacidade vital do ser humano" por meio de uma função educacional pensada como processo unificado e "cujos diferentes graus estão destinados a servir às diferentes fases de seu crescimento" (AZEVEDO et al., 2010, p. 46). O estudante é entendido, assim, como um sujeito que poderia ser levado, progressivamente, a uma plena formação de todas as partes constitutivas de uma totalidade biológica, o indivíduo. Nesta concepção historicamente localizada do que significa ser humano e, mais especificamente, do que significa ser criança, encontramos proposições sobre a aprendizagem como um processo de encadeamento lógico de fases de desenvolvimento psicobiológico. Nesse contexto, as formulações escolanovistas têm como um dos traços distintivos da nomeada escola tradicional a aplicação dos conhecimentos das Ciências Sociais e Biológicas no planejamento, pois alcançavam "por toda a parte o estudo científico e experimental da educação, a libertaram do empirismo, dando-lhe um caráter e um espírito nitidamente científico e organizando, em corpo de doutrina, pesquisas e experiências, os princípios da educação nova" (AZEVEDO et al., 2010, p. 48). 
No que se refere ao ideal de professor pensado para atuar neste tipo de educação, este deve possuir um ideal que o equipe para inculcar às gerações novas sentimentos e hábitos salutares (AZEVEDO et al., 2010, p. 25). Para realizar essa tarefa, ele deve ser formado, além dos estabelecimentos de ensino secundário, em cursos de ensino superior que visem "a [sua] libertação espiritual e econômica", de forma a garantir-lhes "a eficiência no trabalho, a dignidade e o prestígio indispensáveis aos educadores" (AZEVEDO et al., 2010, p. 59) ${ }^{7}$. Em tal formação, a noção de professor é associada com a do sociólogo, articulando como necessário possuir "o conhecimento dos homens e da sociedade em cada uma das suas fases, para perceber, além do aparente e do efêmero, 'o jogo poderoso das grandes leis que dominam a evolução social', e a posição que tem a escola" (AZEVEDO et al., 2010, p. 3435, grifos originais) na organização da pluralidade de forças sociais que constituem o processo civilizatório. Estabelece-se, assim, articulações discursivas entre a Pedagogia e a Sociologia tanto naquilo que se espera do docente quanto na organização das instituições de ensino.

O feixe que une esses dois objetos - a Pedagogia e a Sociologia - é a promessa epistemológica (CARVALHO, 1957, p. 77) de que a Sociologia viria a se tornar um campo de conhecimento capaz de sistematizar e, até certo ponto, antecipar e conduzir os fenômenos sociais, contribuindo para direcionar os resultados de projetos de sociedade. Assim, ainda que o manual didático Introdução Metodológica aos Estudos Sociais estabeleça uma explícita distinção entre as Ciências Sociais como área de referência e a disciplina escolar Estudos Sociais, tendo esta última como objetivo não "propriamente a investigação, mas sim o ensino, a vulgarização" (CARVALHO, 1957, p. 12), isso não significa um desmerecimento do papel de professor. Diferentemente, este possui um papel ainda mais delicado do que o do cientista social, uma vez que exerce funções:

de orientador, de guia, de conselheiro, de auxiliar e colaborador de jovens que se acham em fase decisiva de sua vida social. Deve, pois, o mestre ter uma sólida cultura geral, vistas largas, perspectivas sociais e, além de tudo, se manter continuamente a par da evolução social, política, econômica do mundo em que vive (CARVALHO, 1957, p. 129).

O professor idealizado para atuar na disciplina escolar Estudos Sociais deve despertar no estudante "atitudes em relação às pessoas e às coisas, que o levem a ter consciência do lugar que ocupa na sociedade" (CARVALHO, 1957, p. 66). A preocupação com a formação de caráter ético e a estruturação de atitudes democráticas recebe especial relevo, ainda que isso signifique uma espécie de "transformação íntima", cabendo ao professor "desenvolver mais os processos de ensino do que os seus produtos", tendo em vista que "a livre aceitação [do estudante] é o esteio de um ensinamento" (CARVALHO, 1957, p. 70). É em meio a tal movimento que são também conceitualizados e operacionalizados os tipos de criança a serem ensinadas. Afinal, a significação das etapas de aprendizagem em seriações por graus, que se relacionam às faixas etárias tidas como normais, entrelaça expectativas sociais e características psicobiológicas por meio da noção de desenvolvimento, formulando linhas de 
diferenciação entre os estudantes ao estabelecer parâmetros de normalidade que se confundem com parâmetros de naturalidade.

Tomemos como exemplo as prescrições do manual didático Introdução Metodológica aos Estudos Sociais para a faixa etária entre os onze e doze anos de idade, que é enunciada como aquela na qual se aprofunda a diferenciação entre os sexos, diversificando-se o interesse que manifestam (CARVALHO, 1957). Neste cenário, os meninos se tornam mais atentos às coisas e aos esportes e as meninas ao trato com as pessoas: "para os meninos é o jornal, a equipe, o jogador popular, a marca de automóvel, o modelo de avião", enquanto "para as meninas, os cuidados da casa, dos animais caseiros, da moda e dos desportes elegantes" (CARVALHO, 1957, p. 99, grifos nossos). O interesse pelas ciências e a política vai sendo formulado como uma tendência natural dos meninos (e não das meninas), sugerindo fortemente que, em uma proposta de sociedade democrática na qual os cidadãos devem ser cientificamente capazes e politicamente engajados, a noção de cidadania não era destinada ou pensada de igual modo para todos os estudantes, não dizendo respeito, de certo modo, às meninas.

Em um programa que atribui ênfase em estruturar atitudes e avalia a aprendizagem do estudante como bem sucedida a partir, entre outros critérios, de sua conformação à expectativas comportamentais, esta prática produziu efeitos de verdade que fixaram sentidos e fabricaram tipos de pessoas (HACKING, 2007) acerca dos papéis de gênero, heteronormatividade e discursos racializados e de classe. No manual didático (CARVALHO, 1957), foram construídas necessárias ações educativas de resgate à normalidade, direcionadas aos estudantes que não atendiam certos padrões atitudinais. É nesse contexto que as avaliações recomendadas são constituídas por testes escritos, pela arguição de um tema realizada entre aluno e professor e pela explicação de curtos textos relacionados aos diferentes campos de conhecimento constituintes dos Estudos Sociais, com técnicas específicas para a História, a Geografia e a Sociologia, dentre outras (CARVALHO, 1957, p. 261). Estas práticas avaliativas dão maior ênfase ao ensino disciplinarizado e estabelecem correlações entre os desempenhos individuais e características cognitivas, psicobiológicas e atitudinais dos estudantes. Isso ocorre não apenas na classificação dos estudantes aprovados e reprovados, daqueles que atendem mais ou menos as expectativas dos objetivos escolares, assim como dos professores tidos como muito ou pouco efetivos; ocorre na consubstanciação das diferentes teses culturais que constituem discursivamente o que os objetivos dos Estudos Sociais esperam desses estudantes em formação, os tipos possíveis de crianças que deveriam vir a ser, assim como os profissionais docentes que deveriam ser treinados para leva-las àquele futuro.

No que se refere à BNCC, por sua vez, são as noções de competências e habilidades entrelaçadas que instrumentalizam a organização curricular e, simultaneamente, os tipos de sujeitos da escola. Afinal, o documento afirma que as decisões curriculares nas esferas estaduais e municipais devem ser adequadas a uma ampla gama de modalidades de ensino: a Educação Especial, a Educação de Jovens e Adultos, a Educação do Campo, a Educação Escolar Indígena, a Educação Escolar Quilombola e a Educação à Distância (MEC, 2018a, p. 17). Elas devem, igualmente, abordar um amplo escopo de temas, tais como: os direitos 
da criança e do adolescente; a educação para o trânsito; a educação ambiental; a educação alimentar e nutricional; o processo de envelhecimento, o respeito e valorização do idoso; a educação em direitos humanos; a educação das relações étnico-raciais e o ensino da história e cultura afro-brasileira, africana e indígena; a saúde; a vida familiar e social; a educação para o consumo; a educação financeira e fiscal; o trabalho; a ciência e a tecnologia; a diversidade cultural (MEC, 2018a, p. 19).

É nessa articulação entre modalidades e temas que são fabricados os tipos de sujeitos escolares (HACKING, 2007). As especificidades de ambos - modalidades e temas - devem ser "contempladas em habilidades dos componentes curriculares, cabendo aos sistemas de ensino e escolas, de acordo com suas especificidades, tratá-las de forma contextualizada" (MEC, 2018a, p. 20). É nesse movimento que o estabelecimento de uma diretriz curricular nacional e comum é produzido como uma necessidade para garantir, a todos os brasileiros, a igualdade de acesso e permanência a um mesmo patamar de qualidade por meio da educação pública. É nele, também, que a autonomia dos entes federativos atua como uma garantia na formulação de currículos que satisfaçam as variadas necessidades dos diferentes estudantes em contextos de amplas desigualdades educacionais, com vistas à promoção da equidade. Ou seja, os princípios de inclusão veiculados pela retórica da escolarização moderna são com sucesso seccionados como componentes independentes pela BNCC, cabendo à União a promoção da igualdade e aos sistemas educacionais estaduais e municipais a promoção da equidade. Com isso, o texto curricular acaba por provocar apagamentos e homogeneizações das diferentes características e necessidades dos múltiplos sujeitos escolares; afinal, ainda que a BNCC reconheça a existência das mesmas, ao decidir que a diferença não cabe na esfera federal, ela produz as características que se espera do brasileiro mediano, tratando a expectativa de performance escolar desse tipo de sujeito como o menor denominador comum aceitável e projetando-a como efeito de verdade por todo o território nacional.

As dez competências gerais firmadas pela BNCC corporificam essa expectativa, estabelecendo como principais objetivos para a educação escolarizada brasileira:

1. Valorizar e utilizar os conhecimentos historicamente construídos sobre o mundo físico, social, cultural e digital para entender e explicar a realidade, continuar aprendendo e colaborar para a construção de uma sociedade justa, democrática e inclusiva. 2. Exercitar a curiosidade intelectual e recorrer à abordagem própria das ciências, incluindo a investigação, a reflexão, a análise crítica, a imaginação e a criatividade, para investigar causas, elaborar e testar hipóteses, formular e resolver problemas e criar soluções (inclusive tecnológicas) com base nos conhecimentos das diferentes áreas. [...] 4. Utilizar diferentes linguagens - verbal (oral ou visual-motora, como Libras, e escrita), corporal, visual, sonora e digital -, bem como conhecimentos das linguagens artística, matemática e científica, para se expressar e partilhar informações, experiências, ideias e sentimentos em diferentes contextos e produzir sentidos que levem ao entendimento mútuo. [...] 6. Valorizar a diversidade de saberes e vivências culturais e apropriar-se de conhecimentos e experiências que lhe possibilitem entender as relações próprias do mundo do trabalho e fazer escolhas alinhadas ao 
exercício da cidadania e ao seu projeto de vida, com liberdade, autonomia, consciência crítica e responsabilidade. 7. Argumentar com base em fatos, dados e informações confiáveis, para formular, negociar e defender ideias, pontos de vista e decisões comuns que respeitem e promovam os direitos humanos, a consciência socioambiental e o consumo responsável em âmbito local, regional e global, com posicionamento ético em relação ao cuidado de si mesmo, dos outros e do planeta. [...] 9. Exercitar a empatia, o diálogo, a resolução de conflitos e a cooperação, fazendo-se respeitar e promovendo o respeito ao outro e aos direitos humanos, com acolhimento e valorização da diversidade de indivíduos e de grupos sociais, seus saberes, identidades, culturas e potencialidades, sem preconceitos de qualquer natureza. 10. Agir pessoal e coletivamente com autonomia, responsabilidade, flexibilidade, resiliência e determinação, tomando decisões com base em princípios éticos, democráticos, inclusivos, sustentáveis e solidários (MEC, 2018a, p. 9-10, grifos nossos).

Nesse contexto, a área de conhecimento das Ciências Humanas enumera como um de seus objetivos o "desenvolvimento da autonomia intelectual, bases para uma atuação crítica e orientada por valores democráticos" (MEC, 2018a, p. 354, grifos nossos), reafirmando o papel das Ciências Sociais na fabricação do cidadão democrático e cientificamente capaz. É nele também que o ensino do componente curricular Geografia "constitui-se em busca do lugar de cada indivíduo no mundo, valorizando sua individualidade e, ao mesmo tempo, situando-o em uma categoria mais ampla de sujeito social: a de cidadão ativo, democrático e solidário" (MEC, 2018a, p. 362, grifos nossos).

Em tal movimento, as competências gerais e objetivos da BNCC estabelecem relações com ideais de sociedade que povoam o campo educacional brasileiro. $\mathrm{O}$ documento estabelece relações de continuidade, por exemplo, com a LDB (BRASIL, 1996), os PCNs (BRASIL, 1997) e o PNE (BRASIL, 2014), mobilizando sentidos de uma escola democrática e inclusiva, que pretende reduzir as desigualdades socioeconômicas do país a partir da formação de indivíduos que operem com autonomia e pensamento crítico, estabelecendo uma convivência solidária em sociedade. A construção dessas continuidades, argumentamos, se deu de maneira a angariar legitimidade aos novos enunciados que são colocados em circulação, sendo necessário dialogar com o que já vinha sendo dito, isto é, estabelecendo relações com as condições enunciativas (FOUCAULT, 2015) do campo dos formuladores de políticas públicas educacionais. Participando do estabelecimento dessa política de veridição (BECKER; EWALD; HARTCOURT, 2012), a BNCC opera em meio aos jogos de poder que, historicamente, produzem as verdades sobre os conhecimentos e sujeitos da escola.

Também a noção de desenvolvimento corporificada na BNCC se inscreve como um princípio classificatório na elaboração discursiva da educação escolarizada por seriações em grau, a qual reflete expectativas de aprendizagem relacionadas a características físicas, motoras e cognitivas diretamente associadas à faixas etárias. Além disso, a organização do texto em áreas de conhecimento - capazes de favorecer a comunicação entre os saberes dos diferentes componentes curriculares de forma horizontal (MEC, 2018a, p. 27) - e unidades temáticas definidas como "um arranjo dos objetos de conhecimento ao longo do ensino 
fundamental às especificidades dos diferentes componentes curriculares" (MEC, 2018a, p. 29) orientam a constituição das competências, habilidades e objetos de conhecimento. Nesse processo, são produzidos fragmentos de informação que, ao serem desvinculados historicamente dos conhecimentos a serem ensinados, são apresentados como lógicos e atemporais, produzindo efeitos na fabricação dos sujeitos escolares.

É nesse cenário, portanto, que se fabrica o ideal de profissional eficaz para o ensino dos conhecimentos escolares e, no caso específico desse estudo, aqueles voltados para o ensino da Geografia. Ainda que, para autores como Carlos Roberto Jamil Cury, Magali Reis \& Teodoro Adriano Costa Zanardi (2018, p. 11), até muito recentemente a formação docente era "um ponto em aberto na BNCC, o que dificulta [...] a consolidação de uma Base Nacional Comum Curricular democrática, federativa e diferenciada", o texto oficial já enunciava um alinhamento desta com a implementação da política:

A primeira tarefa de responsabilidade direta da União será a revisão da formação inicial e continuada dos professores para alinhá-las à BNCC. A ação nacional será crucial nessa iniciativa, já que se trata da esfera que responde pela regulação do ensino superior, nível no qual se prepara grande parte desses profissionais. Diante das evidências sobre a relevância dos professores e demais membros da equipe escolar para o sucesso dos alunos, essa é uma ação fundamental para a implementação eficaz da BNCC (MEC, 2018a, p. 21).

Essa explícita articulação entre um ideal de currículo nacional e comum e a formação 'necessária' para a fabricação do professor capaz de implantá-lo 'eficazmente' se dá, como já explicitado, por meio das competências, habilidades e objetos de conhecimento. Em artigo recentemente publicado, Larissa Rodrigues, Beatriz Pereira \& Adriana Mohr (2020) evidenciam esse anunciado alinhamento entre a BNCC e a Proposta para a Base Nacional Comum da Formação de Professores da Educação Básica (doravante BNCFP, MEC, 2018b) ao identificarem que, em ambos os documentos, as competências são idênticas em número e muito semelhantes naquilo que enunciam.

No caso específico do componente curricular Geografia, o professor eficaz é aquele que se pauta nas 'necessidades' disciplinares, assumindo que "os conhecimentos específicos na área de Ciências Humanas exigem clareza na definição de um conjunto de objetos [...]" (MEC, 2018a, p. 354) e que, nesse contexto, "o estudo da Geografia constitui-se em uma busca do lugar de cada indivíduo no mundo [...]” (MEC, 2018a, p. 362). Em consonância com as competências gerais da BNCC, as habilidades e competências do componente curricular participam da fabricação desse professor eficaz. Nelas, o professor eficaz do componente curricular Geografia é atravessado pelos discursos socioambientais, com vistas a desenvolver nos estudantes o raciocínio geográfico (MEC, 2018a, p. 359) e capacitá-los na compreensão da situação geográfica (MEC, 2018a, p.365) do mundo em que vivem a partir de conceitos caros à Geografia contemporânea como espaço, território, lugar, região, natureza e paisagem (MEC, 2018a, p. 361). Observe como essas habilidades e competências são enunciadas no documento oficial: 
1. Utilizar os conhecimentos geográficos para entender a interação sociedade/ natureza e exercitar o interesse e o espírito de investigação e de resolução de problemas. 2. Estabelecer conexões entre diferentes temas do conhecimento geográfico, reconhecendo a importância dos objetos técnicos para a compreensão das formas como os seres humanos fazem uso dos recursos da natureza ao longo da história. 3. Desenvolver autonomia e senso crítico para compreensão e aplicação do raciocínio geográfico na análise da ocupação humana e produção do espaço, envolvendo os princípios de analogia, conexão, diferenciação, distribuição, extensão, localização e ordem. 4. Desenvolver o pensamento espacial, fazendo uso das linguagens cartográficas e iconográficas, de diferentes gêneros textuais e das geotecnologias para a resolução de problemas que envolvam informações geográficas. 5. Desenvolver e utilizar processos, práticas e procedimentos de investigação para compreender o mundo natural, social, econômico, político e o meio técnico-científico e informacional, avaliar ações e propor perguntas e soluções (inclusive tecnológicas) para questões que requerem conhecimentos científicos da Geografia. 6. Construir argumentos com base em informações geográficas, debater e defender ideias e pontos de vista que respeitem e promovam a consciência socioambiental e o respeito à biodiversidade e ao outro, sem preconceitos de qualquer natureza. 7. Agir pessoal e coletivamente com respeito, autonomia, responsabilidade, flexibilidade, resiliência $\mathrm{e}$ determinação, propondo ações sobre as questões socioambientais, com base em princípios éticos, democráticos, sustentáveis e solidários (MEC, 2018a, p. 366, grifos nossos).

Nesse componente curricular, a progressão entre os anos iniciais e finais do ensino fundamental é fortemente articulada à noção de desenvolvimento cognitivo e biológico da criança por meio do significante lugares de vivência. Nos anos iniciais, ele participa da elaboração de "noções de pertencimento, localização, orientação e organização das experiências e vivências em diferentes lugares" (MEC, 2018a, p. 368). Ainda que o próprio documento saliente que as propostas para o componente curricular no segmento não se limitem ao conceito de lugares de vivência, é reiterada a prática dos círculos concêntricos (NASCIMENTO, 2019; PASCAL, 2016; CALLAI, 2005) ao relacionar o acréscimo de complexidade das questões a serem tratadas ao longo dos anos de escolarização, de maneira progressiva, com o acréscimo também progressivo na capacidade do estudante de ir "integrando e ampliando as [suas] escalas de análise" (MEC, 2018a, p. 368). Já nos anos finais, essa tendência se faz ainda mais sentida quando o documento reserva ao sexto ano o ensino da "identidade sociocultural, dos lugares de vivência" (MEC, 2018a, p. 382) e ao sétimo ano o ensino da "formação territorial do Brasil, sua dinâmica sociocultural, econômica e política", enquanto no oitavo e nono anos "o estudo da Geografia se concentra no espaço mundial" (MEC, 2018a, p. 383).

Assumimos, portanto, que o movimento comparativo aqui engendrado requer a compreensão de que, ainda que os Estudos Sociais e a Geografia, em diferentes tempos históricos, mobilizem objetivos educacionais distintos em meio projetos de sociedade que 
produzem sentidos distintos de cidadania, eles se articulam em meio a um sistema de pensamento (POPKEWITZ; LINDBLAD, 2016) que produz o professor eficaz, que participa da formação dos estudantes com vistas à fabricação de cidadãos democraticamente responsáveis e cientificamente capazes. Nesse processo, ainda que os sujeitos, aqui percebidos como alvos em movimento (HACKING, 2007), nunca sejam totalizados por tais categorias, o delineamento de um espaço categórico para pensar e atuar sobre estes sujeitos escolares veio produzindo efeitos de fabricação a partir das verdades educacionais mobilizadas sobre eles. Na próxima seção, explicitamos como os princípios classificatórios operacionalizados pelos Estudos Sociais vieram sendo reatualizados na BNCC, produzindo linhas de diferenciação que constituem as verdades sobre quem somos e o que devemos ensinar e aprender nos processos educativos.

\section{Sobre linhas de diferenciação e o cidadão democrático: apontamentos finais}

Como viemos argumentando, o objeto discursivo cidadão democrático tem sentidos sobre ele mobilizados, tanto na primeira metade do século XX associado aos Estudos Sociais, quanto contemporaneamente, no texto da reforma curricular suscitada pela BNCC. Em ambos os momentos, noções de solidariedade e cooperação, assim como o desenvolvimento do pensamento crítico por meio da capacitação científica do cidadão, povoam os discursos, estabelecendo como objetivos para a instituição escolar participar da organização de um projeto de sociedade democrático, justo e inclusivo. No âmbito do movimento escolanovista, entre as décadas de 1930 e 1960, por exemplo, as bandeiras educacionais eram a garantia da oferta de uma educação gratuita, laica, obrigatória e universal como uma necessidade para a democratização da sociedade, em contraponto direto a tendências centralizadoras advindas do período do Estado Novo, assim como tendências privatizadoras que atacavam à época a escola publicamente gerida (AZEVEDO et al., 2010). O cidadão democrático articulado pelos discursos da BNCC, por sua vez, é constituído pela urgência da melhoria de uma educação pública em crise, recolocando a universalidade do sistema em outros termos ao associar a constituição de um currículo nacional e o comum a noções de qualidade, igualdade e equidade.

Isso significa pensar que, ainda que a disputa pela significação desse objeto discursivo tenha se dado em momentos históricos distintos, com objetivos educacionais específicos, permanecemos operando com a noção de que cabe à escola, em tempos de democracia, fabricar o cidadão democrático. Para realizar essa tarefa, torna-se necessária a constituição de um professor eficaz que, a partir do movimento escolanovista, necessita de formação em nível superior não apenas para se tornar ele mesmo cientificamente capaz, mas para a valorização da profissão como um todo (AZEVEDO et al., 2010, p. 59). É nesse contexto que a Biologia, a Psicologia e a Sociologia se tornam necessárias, informando a condução de avaliações pontuais e continuadas sobre os estudantes, com vistas a desenvolver comportamentos e estruturar atitudes (CARVALHO, 1957, p. 74). No tempo presente, por 
sua vez, o professor eficaz será aquele que, além de formado em nível superior, seja capaz de implementar a BNCC, razão pela qual as políticas curriculares devem estar articuladas, produzindo "um alinhamento entre o que se espera que se aprenda pelos alunos na educação básica e o que se espera que os professores aprendam e ensinem" (RODRIGUES, PEREIRA \& MOHR, 2020, p. 30).

Podemos dizer, então, que ainda que esses tempos históricos tenham produzindo sentidos diversos para a cidadania democrática, é a partir da concepção de desenvolvimento que estas linhas de diferenciação efetivamente se conjugam. Nos programas da disciplina escolar Estudos Sociais, no início do século XX no Brasil (CARVALHO, 1957), por exemplo, era a partir do desenvolvimento da criança que eram traçadas as distinções entre os sujeitos de pensamento crítico e científico e os outros, entrelaçando expectativas sociais e características psicobiológicas do crescimento dos indivíduos. Esses outros, explicitamente enunciados entre as décadas de 1940 e 1960, foram sendo fabricados em meio à sentidos de heteronormatividade e de gênero, assim como discursos racializados e de classe, situando-os fora do âmbito da ciência e da política em meio à imperativos considerados da ordem do biológico. Na BNCC, por sua vez, esses aspectos não são mais enunciados como expectativas socioculturais amalgamadas a características psicobiológicas por meio da ideia de desenvolvimento. Encontramos, porém, nas unidades temáticas do componente curricular Geografia, a articulação de objetivos de ensino-aprendizagem progressivamente mais complexos na medida em que a criança avança no ensino fundamental, recolocando a noção de desenvolvimento em outros termos. Tal noção operacionaliza, de certo modo, um modelo análogo ao dos círculos concêntricos, uma abordagem explicitamente associada ao movimento escolanovista (NASCIMENTO, 2019; PASCAL, 2016; CALLAI, 2005), reativando linhas de diferenciação a partir de expectativas de normalidade por meio de um amadurecimento linear e indissociável das funções cognitivas, sociais e corporais.

Além disso, em um contexto de transformações importantes nas tendências populacionais de inserção desses outros no cenário educacional e no mundo do trabalho, a BNCC permanece produzindo esses outros ao legitimar a necessidade de uma diretriz curricular comum e nacional que combata a naturalização das desigualdades educacionais "entre os grupos de estudantes definidos por raça, sexo e condição socioeconômica de suas famílias" (MEC, 2018a, p. 15). Isso não significa negligenciar os processos históricos de exclusão desses outros nos processos de escolarização no país; diferentemente, significa assumir, no diálogo com Thomas Popkewitz (2001), que as lutas por inclusão também operam em meio a jogos de saber e poder que são produtoras de exclusões. $\mathrm{O}$ entendimento de tal questão, segundo esse autor, nos auxilia a produzir investigações que desafiam os valores morais que informam as políticas educacionais como objetos da lógica, desestabilizando "as formas disponíveis de raciocínio que internalizam e fecham os espaços ocupados pelos professores e pelas crianças, abrindo esses espaços para outras possibilidades" (POPKEWITZ, 2001, p. 15). No caso específico desse trabalho, significa pensar como o espaço discursivo do outro da educação formal no país é por vezes irrefletidamente ativado como parte do senso comum, mesmo quando advogamos a melhoria da qualidade por meio de um currículo nacional e comum (SANTOS; FERREIRA, 2020). 
Não buscamos, portanto, com a análise aqui apresentada, formular interpretações denuncistas que se apoiam em um mundo fora desses jogos de saber e poder; não pretendemos, também, aproximar de forma irrefletida períodos históricos distintos. O que fizemos foi historicizar os processos discursivos que, por meio de práticas alquímicas (POPKEWITZ, 2001), deram forma aos princípios classificatórios que vieram sendo operacionalizados pelos Estudos Sociais e, posteriormente, a Geografia. Ou seja, ainda que a retórica educacional contemporânea que produz a BNCC não seja a mesma dos anos de 1946 a 1964, no tempo presente se reatualizam princípios classificatórios considerados adequados ao desenvolvimento do estudante, conjugando características psicobiológicas com expectativas sociais e que são tomadas como parte lógica e estável das "infraestruturas conceituais e institucionais" (KIRCHGASLER, 2017) da escola.

Por fim, ao problematizar os processos discursivos que deram forma aos princípios classificatórios que participaram ativamente da constituição do estudante brasileiro como um cidadão democrático e cientificamente capaz, com foco na participação das Ciências Sociais, pudemos contribuir para desestabilizar as verdades do ensino desses conhecimentos em tempos de democracia. Afinal, sem esse tipo de reflexão acerca das linhas de diferenciação que vieram fabricando os sujeitos da educação - estudantes e professores - nesses tempos no país, corremos o risco de mantê-las inscritas e invisíveis nas infraestruturas conceituais e institucionais da escolarização. Reafirmamos, portanto, que historicizar essas linhas de diferenciação, tornando as condições de emergência de certas feições epistemológicas visíveis, a fim de desnaturalizá-las como objetos lógicos e estáveis, abre espaço para que outras maneiras de pensar sobre a educação possam respirar, produzindo outras verdades possíveis.

\section{Notas}

1. Reconhecemos, destarte, a natureza contenciosa em alguns circuitos deste enunciado. Tendo em vista que este constitui apenas parte de nossa justificativa para o delineamento do objeto de pesquisa de um certo modo e não de outros, não sendo nem objeto em si nem parte central do referencial, é suficiente então admiti-lo como posicionamento pessoal, alinhado com produções e autores como Jinkings, Doria e Cleto (2016), Cury, Reis e Zanardi (2018), Rodrigues, Pereira e Mohr (2020), entre outros.

2. AMORIM, F. PEC do Teto é aprovada em votação final e congela gastos por 20 anos. UOL Notícias, 13 dez 2016. Disponível em <https://noticias.uol.com.br/politica/ultimas-noticias/2016/12/13/pec-que-congela-gastos-do-governopor-20-anos-e-aprovada-em-votacao-final.htm>.

3. CAVALINNI, M. Reforma trabalhista é aprovada no senado: confira o que muda na lei. G1 Globo Economia, 11 jul 2017. Disponível em: <https://g1.globo.com/economia/noticia/reforma-trabalhista-e-aprovada-no-senado-confira-oque-muda-na-lei.ghtml>.

4. Vale ressaltar que tanto Ian Hacking (2007) quanto Michel Foucault (2015) estabelecem interlocuções com o conhecimento científico, em diferentes momentos sócio-históricos.

5. Na língua inglesa, autores como Thomas Popkewitz utilizam o significante matéria para nomear os componentes dos currículos escolares, em contraposição ao termo disciplina, que é utilizado nos currículos universitários. Aqui, diferentemente, seguimos uma tradição acadêmica brasileira de nomear ambos os componentes curriculares, na escola e na universidade, de disciplina.

6. As cinco bases das quais o manual didático lança mão são elaboradas a partir do diálogo com os parâmetros que o professor T. H. Schutte estabeleceu, em 1938 (Teaching the social studies on the secondary school level). 
7. Para o movimento escolanovista, a hierarquização em importância e remuneração entre mestres, professores e catedráticos, baseadas no tipo de formação de cada uma dessas categorias, não eram condizentes com a unidade da função educacional, característica necessária para o estabelecimento de um sistema educacional nacional verdadeiramente democrático (AZEVEDO et al., 2010, p. 59).

\section{Referências bibliográficas}

AZEVEDO, F. ... [et al.] Manifestos dos Pioneiros da Educação Nova (1932) e dos Educadores (1959). Recife: Fundação Joaquim Nabuco, Editora Massagana, 2010.

BECKER, G; EWALD, F.; HARTCOURT, F. Becker on Ewald on Foucault on Becker: American Neoliberalism and Michel Foucault's 1979 'Birth of Biopolitics' Lectures. Coase-Sandor Institute for Law \& Economics Working Paper No. 614, 2012. Disponível em: <https://chicagounbound.uchicago.edu/ cgi/viewcontent.cgi?article=1076\&context=law_and_economics>, Acesso em: 28 dez 2019.

BRASIL. Lei de Diretrizes e Bases da Educação Nacional. Lei no 9.394 de 20 de Dezembro de 1996. Disponível em: 〈http://portal.mec.gov.br/seed/arquivos/pdf/tvescola/leis/lein9394.pdf〉. Acesso em 05 julho 2013.

BRASIL. Secretaria de Educação Fundamental. Parâmetros Curriculares Nacionais: Introdução aos Parâmetros Curriculares Nacionais/Secretaria de Educação Fundamental. Brasília: MEC/SEF, 1997. Disponível em: <http://portal.mec.gov.br/seb/arquivos/pdf/livro01.pdf>. Acesso em: 02 nov 2017.

BRASIL. Lei n 13.005 , de 25 de junho de 2014. Brasília, DF: Diário Oficial da União, 2014. Disponível em: <http://www.planalto.gov.br/ccivil_03/_ato2011-2014/2014/lei/113005.htm>. Acesso em: 20 dez 2019.

BRASIL. Parâmetros Curriculares Nacionais para o Ensino Médio. Brasília: Ministério da Educação e Cultura, 1999.

BRASIL. MEC. Secretaria de Educação Média e Tecnológica. PCNs+ Ensino Médio: orientações educacionais complementares aos Parâmetros Curriculares Nacionais. Brasília, 2002. 144 p

BRASIL. Orientações Curriculares Nacionais para o Ensino Médio. Brasília: Ministério da Educação e Cultura, 2006.

CALLAI, H. C. Aprendendo a Ler o Mundo: a geografia nos anos iniciais do ensino fundamental. Cad. Cedes, Campinas, vol. 25, n. 66, p. 227-247, maio/ago. 2005. Disponível em: Disponível em $<$ http://www.cedes.unicamp.br.>

CARVALHO, D. Introdução Metodológica aos Estudos Sociais. Rio de Janeiro: Livraria Agir Editora, 1957.

CHARRET, H. C. Integração Curricular nas Reformas do Ensino Médio: estabilidade e mudança no embate entre as áreas de conhecimentos e as disciplinas escolares. Tese (Doutorado em Educação). Rio de Janeiro: PPGE/UFRJ, 2019.

CURY, R.; REIS, M.; ZANARDI, T. (Org.) Base Nacional Comum Curricular: dilemas e perspectivas. São Paulo: Cortez, 2018.

FERREIRA, M. S. História do Currículo e das Disciplinas: apontamentos de pesquisa. In: André Márcio Picanço Favacho; José Augusto Pacheco; Shirlei Rezende Sales. (Org.). Currículo, conhecimento e avaliação: divergências e tensões. Curitiba: CRV, p. 75-88, 2013.

FERREIRA, M. S. História do Currículo e das Disciplinas: produzindo uma abordagem discursiva para investigar a formação inicial de professores nas Ciências Biológicas. In: Miriam Soares Leite; Carmen Teresa Gabriel (Org.). Linguagem, Discurso, Pesquisa e Educação. 1ed.: DePetrus/FAPERJ, 2015, p. 265284.

FERREIRA, M. S.; MARSICO, J. Historicizar os currículos em tempos recentes: regulações e efeitos no ensino e na formação de professores em Ciências e Biologia. In: Marcia Serra Ferreira; Silvia Nogueira Chaves; 
Antonio Carlos Rodrigues de Amorim; Maria Luiza de Araújo Gastal; Sandra Nazaré Dias Bastos. (Org.). Vidas que ensinam o ensino da vida. 1ed. Belém: Editora Livraria da Física, 2020, p. 165-179.

FERREIRA, M. S.; SANTOS, A. V. F. Discursos curriculares no/do tempo presente: subsídios para uma articulação entre a História e as Políticas de Currículo. In: Alice Casimiro Lopes; Marcia Betania de Oliveira. (Org.). Políticas de Currículo: pesquisas e articulações discursivas. 1ed. Curitiba: CRV, 2017, v. 1, p. 55-78.

FOUCAULT, M. O sujeito e o poder. In.: DREYFUS, H. L.; RABINOW, P. Michel Foucault - Uma Trajetória Filosófica: para além do estruturalismo da hermenêutica. Rio de Janeiro: Forense Universitária, 1995.

FOUCAULT, M. A Arqueologia do Saber. 8. ed. Rio de Janeiro: Forense, 2015.

FRANÇA, A. S. Propostas Curriculares para o Ensino de Estudos Sociais: circulações e apropriações de representações de ensino de história e de aperfeiçoamento de professores (Espírito Santo, 1956 - 1976). Tese (Doutorado em Educação). Espírito Santo: UFES, 2013.

FRIEDRICH, D.; JAASTAD, B.; POPKEWITZ, T. Democratic Education: An (Im)possibility that yet Remains to Come. Educational Philosophy and Theory. 42. 571 - 587, 2010.

HACKING, I. Kinds of People: Moving Targets. In Proceedings of the British Academy, Volume 151, 2006 Lectures. pp. 285-318, 2007. Disponível em: < https://www.thebritishacademy.ac.uk/sites/default/files/ pba151p285.pdf >. Acesso em 13 dez. 2019.

JINKINGS, I.; DORIA, K.; CLETO, M. (ORG.). Por que gritamos Golpe? São Paulo: Boitempo, 2016.

KIRCHGASLER, K. L. Scientific Americans: Historicizing the making of difference in early 20thcentury U.S. science education. In: Thomas S. Popkewitz; Jennie Diaz; Christopher Kirchgasler. (Eds.), A Political Sociology of Educational Knowledge: Studies of Exclusions and Difference. New York: Routledge (pp. 87102). New York: Routledge, 2017.

KOSELLECK, R. Futuro Passado: contribuição à semântica dos tempos históricos. Editora PUC-Rio, Contraponto 368p. 2006.

MEC. Base Nacional Comum Curricular. Brasília: MEC, 2018a.

MEC. Proposta para Base Nacional Comum da Formação de Professores da Educação Básica. Brasília: MEC, 2018b. Disponível em: <http://portal.mec.gov.br/index.php?option=com_docman\&view=download\&alias $=105091$-bnc-formacao-deprofessores-v0\&category_slug=dezembro-2018-pdf\&Itemid=30192>. Acesso em 20 jan 2020.

MICHAELIS, J. U. Estudos Sociais para Crianças numa Democracia. 2. ed. Porto Alegre: Editora Globo, 1970.

MORAES, L. M. S. A Disciplina Estudos Sociais nos Anos Iniciais do Colégio Pedro II: disputas e negociações curriculares em perspectiva. Tese (Doutorado em Educação). Rio de Janeiro: PPGE/UFRJ, 2017.

NASCIMENTO, T. O Ensino de Estudos Sociais no Brasil: das "connexões naturaes" à integração pela via do autoritarismo (1930-1970). Tese (Doutorado em Educação). Rio de Janeiro: PUC-Rio, 2019.

NADAI, E. Estudos Sociais no Primeiro Grau. Revista Em Aberto, ano 7, no 37, jan./mar. Brasília, 1988. Disponível em <http://emaberto.inep.gov.br/index.php/emaberto/issue/view/198>. Acesso em 05. mar. 2014.

OLIVEIRA, I. Políticas Curriculares no contexto do golpe de 2016: debates atuais, embates e resistências. In.: Marcia Ângela da S. Aguiar; Luiz Fernandes Dourado. (Org.) A BNCC na contramão da PNE 2014-2024: avaliação e perspectivas. Recife: ANPAE, 2018.

PASCAL, G. M. O Ensino de Geografia nos Anos Iniciais do Ensino Fundamental: uma perspectiva a partir da análise dos livros didáticos aprovados pelo PNLD 2013. São Paulo: Unifesp, 2016. Dissertação (Mestrado em Educação) - Programa de Pós- Graduação em Educação, 2016. 
PEDRO, G. A Alquimia das Disciplinas Escolares em Tempos Democráticos no Brasil: Fabricando Sujeitos a partir dos Conhecimentos Geográficos no Ensino Fundamental. 233p. Tese (Doutorado em Educação). Rio de Janeiro: PPGE/UFRJ, 2020.

POPKEWITZ, T. S. Lutando em defesa da alma: a política do ensino e a construção do professor. Porto Alegre: Artmed, 2001.

POPKEWITZ, T. S. Numbers in grids of inteligibility: Making sense of how educational truth is told. In.: Hugh Lauder; Michael Young; Harry Daniels; Maria Balarin; John Lowe. (Org.) Educating for Knowledge Economy? Critical perspectives. London: Routledge, p.169-191, 2012.

POPKEWITZ, T.; LINDBLAD, S. Statistics Reasoning, Governing Education, and Social Inclusion and Exclusion. Educação e Sociedade, Campinas, v. 37, n. 136, p. 727-754, Set. 2016. Disponível em: $<$ http://www.scielo.br/scielo.php?script=sci_arttext\&pid=S0101$73302016000300727 \& \operatorname{lng}=$ en\&nrm=iso>. Acesso em 20 dez. 2019.

RODRIGUES, L.; PEREIRA, B.; MOHR, A. O Documento "Proposta para Base Nacional Comum da Formação de Professores da educação Básica" (BNCFP): Dez Razões para Temer e Contestar a BNCFP. Revista Brasileira de Pesquisa em Educação em Ciências, v. 20, jan.-dez. 2020.

SANTOS, A. V. F.; FERREIRA, M. S. Currículo nacional comum: uma questão de qualidade? Revista Em Aberto, Brasília, v. 33, n. 107, p. 27-44, jan./abr. 2020. Disponível em: <http://rbepold.inep.gov.br/index.php/emaberto/article/view/4528/pdf>.

SÜSSEKIND, M. L. As (im)possibilidades de uma Base Comum Nacional. Revista e-curriculum, v. 12, n. 03, p. 1512-1529, out./dez. 2014. Disponível em: <https://revistas.pucsp.br/curriculum/article/view/ 21667/15917> Acesso em: 20 dez 2019.

TENORIO, F. G. A modernidade e a pós-modernidade servidas em dois jantares. Cadernos EBAPE.BR, v. 7, n. 3, p. 472-491. Rio de Janeiro, 2009. Disponível em: <http://www.scielo.br/scielo.php?script= sci_arttext\&pid=S1679-39512009000300006\&lng=en\&nrm=iso >. Acesso em: 10 jan. 2020.

\section{Correspondência}

Gabriel Pedro: Professor de Geografia, é Doutor em Educação pela Universidade Federal do Rio de Janeiro e pesquisador associado ao Grupo de Estudos em História do Currículo.

E-mail: gabriel.brasil.88@gmail.com

Marcia Serra Ferreira: Professora da Universidade Federal do Rio de Janeiro, atuando na Faculdade de Educação e no Programa de Pós-Graduação em Educação. É bolsista de produtividade 2 do CNPq e Cientista do Nosso Estado (CNE/Faperj). Coordena o Grupo de Estudos em História do Currículo.

E-mail: marciaserraferreira@gmail.com

Texto publicado em Currículo sem Fronteiras com autorização dos autores 